\title{
KOMPARATIVNA ANALIZA JUGOSLOVENSKO-TURSKE KONVENCIJE IZ 1938. I "DŽENTLMENSKOG SPORAZUMA" IZ 1953. Pregovori oko iseljavanja muslimana iz Jugoslavije u Tursku
}

\begin{abstract}
APSTRAKT: Autor kontekstualizira i tematizira dva sporazuma između Jugoslavije i Turske - jugoslovensko-tursku konvenciju (1938) i "džent/menski sporazum" iz 1953. - u kojima se definišu uslovi iseljavanja muslimanskog stanovništva. Uspoređuje ulogu kraljevske vlade u pregovorima vođenim do 1940. sa ulogom koju je jugoslavenska vlada u istom kontekstu odigrala pedesetih godina. Uz to posebnu pažnju posvećuje imigracijskoj politici Turske i represivnim mjerama koje su poduzete prema neslavenskom, prvenstveno albanskom, muslimanskom stanovništvu.
\end{abstract}

Ključne riječi: Milan Stojadinović, jugoslavensko-turska konvencija (1938), "džentlmenski sporazum" (1953), interministerijalne konferencije (1935), zakon o državljanstvu (1928, §55), državna represija, turska imigracijska politika

\section{Uvod}

Migracijski procesi, kao dio naše svakidašnjice, ne predstavljaju ništa neobično. Oni su dio lokalnih i globalnih društvenih zbivanja i historijskih tokova. Mogu se odvijati kako u našem bližem okruženju tako i prelaziti administrativne, odnosno državne granice i dugoročno gledano ostavljaju uticaje na sredine koje tangiraju. Za vrijeme 19. i 20. stoljeća migracijski su tokovi dostigli „novi kvalitet”. Pod geslom modernizacije i industrijalizacije, a naročito u sjenci korjenitih društveno-političkih promjena kao što su ratna dešavanja, migracijski su se procesi drastično pojačavali. To se odnosi na cijelu Evropu, kao i na prvu i drugu Jugoslaviju, gdje su se državne institucije suočavale sa pitanjem regulisanja odnosno uticaja na migracijske procese pod socio-političkim, ekonomskim, ideološkim ili drugim premisama.

U našem konkretnom slučaju se radi o emigraciji muslimanskog stanovništva u Tursku iz onih dijelova Jugoslavije koji su najduže ostali pod osmanskom vlašću: cijeli Kosovski vilajet (Stara Srbija) kao i dijelovi Manastirskog i Solunskog vilajeta. Oni obuhvataju delove takozvanog Novopazarskog sandžaka, te geografsko-administrativne jedinice konstituisane poslije Drugog svjetskog rata: Autonomna Kosovsko-metohijska oblast - koju ćemo u daljem tekstu iz pragmatičnih razloga nazvati samo Kosmet - kao i Makedonije. 
Migranti sa tih područja su sačinjavali prilično heterogenu grupu, čiji su se pripadnici međusobno razlikovali po jeziku (slavenski jezici vs. albanskog i turskog) i etničkoj pripadnost (Albanci, Bošnjaci/muslimani, Turci, Goranci, Pomaci, Torbeši).

U kulturi sjećanja kao i u historijskom narativu tih grupa iseIjavanje u Tursku je ostavilo duboke tragove, posebno u njihovom samopozicioniranju u istoriji Jugoslavije. To se osobito odnosi na Albance koji su za vrijeme postojanja Jugoslavije često imali vrlo napete odnose sa Beogradom. U ovom diskursu se iseljavanje u Tursku asocira sa državnom represijom i srpskim nacionalizmom, te predstavlja u albanskom nacionalnom narativu i u albanskoj istoriografiji važan elemenat. U tom kontekstu se jugoslavensko-turska konvenciju iz 1938. i takozvani "džentImenski sporazum" iz 1953. smatraju simbolima jedne kontinuirane državne politike koja je bila usmjerena ka protjerivanju albanskog stanovništva (sa Kosova). Pri tome se često ne pravi razlika između prvog i drugog ugovora, već se sporazum iz 1953. smatra kao implementacija konvencije iz 1938. godine. ${ }^{1}$

Dok se već za vrijeme SFRJ znalo prilično puno o konvenciji iz $1938,{ }^{2}$ sličnih istraživanja o kasnijem sporazumu skoro da nije bilo. Hakif Bajrami je objavio jedan upitan dokument - u kojem se radi o protokolu navodnog razgovora Josipa Broza Tita sa turskim ministrom inostranih poslova Fuatom Köprülüem, kojeg Bajrami identificira kao "džentlmenski sporazum" iz 1953. i kojeg dovodi u vezu sa konvencijom iz 1938. godine. ${ }^{3}$ No sumnje u tezu postojećeg kontinuiteta konvencije iz 1938. se javljaju čitajući pismo iz sredine marta

1 Vidjeti na primjer potpoglavlje o Kosovu u izdanju Akademije nauka Albanije Historia e Popullit Shqiptar. Tom 4: Shqiptarët gjatë luftës së Dytë Botërore dhe pas saj. 1939-1990, Tiranë, 2008, str. 403.

2 Već šezdesetih godina su Živko Avramovski i Ali Hadri tematizirali iseljeničku politiku jugoslovenske vlade. Nekoliko godina kasnije je Vuk Vinaver detaljnije opisao tok razgovora između Jugoslavije i Turske od 1935. a objavio je i relevantne detalje konvencije. Hakif Bajrami je onda u osamdesetim godinama objavio francuski tekst konvencije („Konventa jugosllavo-turke") kao i albanski prijevod transkripta međudržavne komisije koja je pripremila konvenciju ("Rreth përgatitjes së Konventës jugosllave-turke"), dok je Avdija Avdić početkom 90-ih objavio sažetak tih transkripta i konvencije na srpskohrvatskome. Vidjeti: Živko Avramovski, „Prilog pitanju italijansko-albanske iredentističke propagande na Kosovu i Metohiji u vreme minhenske krize i okupacije Albanije", Istorijski glasnik, 2-3/1964, str. 123-140; Ali Hadri, "Kosovo i Metohija u Kraljevini Jugoslaviji”, Istorijski glasnik, 1-2/1967, str. 51-84; Vuk Vinaver, "'Çështja shqiptare' në shtypin e PKJ 19191939", Gjurmime albanologjike. Seria e shkencave historike, 1/1971, str. 65101; Hakif Bajrami, "Konventa jugosllavo-turke e vitit 1938 për shpërnguljen e shqiptarëve", Gjurmime albanologjike. Seria e shkencave historike, 12/1982, str. 243-271; Hakif Bajrami, „Rreth përgatitjes së Konventës jugosllave-turke për shpërnguljen e shqiptarëve në Turqi (1938)", Gjurmime albanologjike. Seria e shkencave historike, 18/1988, str. 209-238; Avdija Avdić, „Jugoslovensko-turski pregovori o iseljavanju muslimanskog stanovništva u periodu između dva svetska rata", Novopazarski zbornik, 15 (1991), str. 112-125.

3 Hakif Bajrami, "Marrëveshja xhentelmene Tito-Kyprili më 1953 në Split", Vjetar, 25-26/2001, str. 259-306, ovdje str. 272-275. 
1954. kojim se Aleš Bebler, državni podsekretar za inostrane poslove, obratio poslanstvu FNRJ u Hagu. Naime, Bebler je pisao:

"Ristiću. Molimo izvestite što detaljnije o sporazumu koji je potpisan pre rata izmedju Jugoslavije i Turske o pitanju iseljavanja turske manjine iz Jugoslavije. Da li vam je poznato gde bi se taj sporazum mogao naćí? Inače, detaljno po sećanju skicirajte svu materiju koja se odnosi na ovo pitanje i dostavite." ${ }^{4}$ [podvučeno kao u originalu - E. P.]

Primalac tog pisma bio je najvjerovatnije Milan A. Ristić, nekadašnji šef Balkanskog odsjeka Ministarstva inostranih poslova, koji je u 1938. vodio pregovore sa turskom stranom o sklapanju konvencije o iseljavanju neslavenskog muslimanskog stanovništva iz "Južne Srbije" (Stara Srbija i jugoslovenski deo Makedonije)..$^{5}$ To nas dovodi do ključnih pitanja: šta je socijalističko rukovodstvo znalo o konvenciji, koju ulogu su odigrali jugoslavenski državni funkcioneri u procesu sklapanja sporazuma iz 1953. godine, i da li su preuzeli elemente iz konvencije, odnosno njenu intenciju koja je bila usmjerena ka što većem iseljavanju albanskog stanovništva?

U cilju pronalaženja odgovora na ova pitanja ćemo uporediti društveno-političke okolnosti za vrijeme nastanka oba sporazuma, kao i udio državnog vrha prve odnosno druge Jugoslavije u iseljeničkoj politici prema Turskoj, ne zanemarajući ni Tursku kao jednog od ključnih aktera.

\section{Jugoslovensko-turska konvencija. O početku razgovora}

Pitanje iseljavanja muslimanskog stanovništva u Tursku ostalo je i poslije raspada Jugoslavije u fokusu naučnih radova. Posebno su Safet Bandžović, a u posljednje vrijeme Jovan Jovanović za međuratni period, i Borče Ilievski poklanjali pažnju ovoj tematici. ${ }^{6}$ Ipak su neki "detalji" ostali nerazjašnjeni, kao na pri-

4 Arhiv Saveznog ministarstva inostranih poslova (dalje ASMIP), Politička arhiva (dalje PA) 1954 - F 97, [Beograd], 43274/16. 3. 1954.

5 Treba napomenuti da je pojam „Južna Srbija" u međuratnom periodu mogao da ima različita značenja, kao sinonim samo za Makedoniju ili za cijelu teritoriju bivšeg Osmanskog carstva koju su prisvojile Srbija i Crna Gora za vrijeme Prvog balkanskog rata. Vidjeti: Vladan Jovanović, Jugoslovenska država i Južna Srbija 1918-1929. Makedonija, Sandžak, Kosovo i Metohija u Kraljevini SHS, Beograd, 2002, str. 7-9. Jasno je da je to za pravoslavno stanovništvo značilo oslobođenje. Ali uzimajući u obzir rezultate popisa iz 1921. god. kada je na prostoru "Južne Srbije" (Sandžak, Kos., Makedonija) - to cijelo područje je za mene relevantno - izbrojan odnos 50,06\% (739.278, pravoslavno stanovništvo) prema 48,18\% (711.481, muslimansko stanovništvo) i znajući da su balkanski ratovi zbog masovnog iseljavanja/protjerivanja muslimana značili i izraziti demografski pad za muslimane, onda mislim da je muslimansko stanovništvo koje se sredinom 1912. zateklo na tom području činilo značajnu većinu, daleko preko 50\%; a za njih se teško može kazati da su oslobođeni

6 Safet Bandžović, Iseljavanje Bošnjaka u Tursku, Sarajevo, 2006. Vidjeti od 
mjer početak razgovora, ko je i zašto preuzeo inicijativu za sklapanje konvencije, kakva je uloga predsjednika jugoslovenske vlade Milana Stojadinovića koji je za vrijeme sklapanja konvencije bio ministar vanjskih poslova? Tako se i dalje u literaturi o početku pregovora između Jugoslavije i Turske nailazi na različite datume. To se već vidi posmatrajući dva često citirana članka Alija Hadrija i Živka Avramovskog. Hadri na primjer konstatira - oslanjajući se na peticiju trojice albanskih katoličkih sveštenika upućenu Društvu naroda (5. 5. 1930) - da je već 1930. godine jugoslavenska vlada počela pregovore sa turskom vladom i da je Bogoljub Jevtić 1931. postigao načelnu saglasnost sa turskim ministrom vanjskih poslova Rüştüem Arasom. ${ }^{7}$ Avramovski, međutim, piše da su kontakti o pitanju iseljavanja muslimana iz Jugoslavije u Tursku počeli 1935, za vrijeme Jevtićeve vlade. ${ }^{8}$

Spomenuta peticija iz 1930. godine nije precizna, nego je u vremenskom okviru sasvim neodređena, a i sama tvrdnja ta tri sveštenika, da je beogradska vlada pokrenula razgovore sa vladom u Ankari "on the transfer to Turkey of three to four hundred thousand Albanian Moslems from Kosovo", problematična. ${ }^{9}$ Razlog sumnji je i to što je turska vlada od sredine 20 -ih godina vodila restriktivnu politiku prema useljenicima sa Balkana, pogotovo prema Albancima, što ćemo kasnije još razmatrati. Što se 1931. odnosno 1935. godine tiče, zanimljivo je da su Hadri i Avramovski, koristeći se istim izvorom, naime pozivajući se na dopis savjetnika ministra vanjskih poslova Ive Andrića Poslanstvu Kraljevine Jugoslavije u Ankari od 26. septembra 1935, došli do različitih zaključaka. Po tome dopisu je Aras u razgovoru sa vršiocem dužnosti jugoslavenskog stalnog delegata u Ženevi Ivanom Subotićem, vjerovatno sredinom septembra 1935, izjavio da je u "svoje doba (vremenski okvir nije jasan - E. P.) imao razgovor sa bivšim Ministrom g. Jevtićem o iseljavanju turskog i ostalog muslimanskog neslovenskog

njegovih mnogobrojnih članaka: Safet Bandžović, "Iseljavanje muslimanskog stanovništva iz Jugoslavije u Tursku između dva svjetska rata", Almanah, 1718/2001, str. 171-224. Vladan Jovanović, "Iseljavanje muslimana iz Vardarske banovine. Između stihije i državne akcije", Pisati istoriju Jugoslavije. Viđenje srpskog faktora, (ur. Mile Bjelajac), Beograd, 2007, str. 79-99. Vidjeti u vezi sa iseljavanjem iz Makedonije, centra iseljavanja u Tursku u pedesetim godinama: Violeta Ačkoska, "Iseluvanjeto na Turcite od NR Makedonija po vtorata svetska vojna (1945-1960)", Istorija, 38, 1-2, Skopje, 2002, str. 89-102; Borče Ilievski, "The Ethno-Demographic Changes in the 1950s in the People's Republic of Macedonia. The Emigration Process of the Turkish and Muslim Population", Macedonian Historical Review, 1/2010, str. 167-182.

7 A. Hadri, n. d., str. 75.

8 Ž. Avramovski, n. d., str. 125.

9 Engleski prijevod sa francuskog originala te peticije se može naći na internetstranicama albanologa Roberta Elsiea: http://www.albanianhistory.net/ texts20 2/AH1930.html, Gjon Bisaku, Shtjefën Kurti \& Luigj Gashi: The Situation of the Albanian Minority in Yugoslavia. Memorandum Presented to the League of Nations. Vidjeti ovdje Appendix II, tačka II/4. 
(ovde se radi o Arbanasima) življa iz Jugoslavije. Između njih je bio sporazum načelno postignut da se to iseljavanje favorizira od strane naše zemlje". ${ }^{10}$

Kao vrijeme tog razgovora se može isključiti 1931. godina, jer je Jevtić tek 3. jula 1932. zauzeo mjesto ministra inostranih poslova. Spomenuti razgovor se dogodio najvjerovatnije poslije zbližavanja Jugoslavije i Turske, kad je potpisan tursko-jugoslavenski (novembar 1933) odnosno Balkanski pakt (februar 1934), na primjer za vrijeme Jevtićevog boravka u Ankari (april 1934), gdje se između ostalih susreo sa Arasom. No, Jevtić se sreo sa Arasom i u Bukureštu u sklopu razgovora oko Balkanskog saveza u maju 1935. godine, te je moguće da je sporazum postignut i tom prilikom.

Ovo pitanje postaje interesantnije gledajući tursku imigracijsku politiku, jer je to kontekst u kojem moramo promatrati gornju izjavu. Naime, Turska je 14. juna 1934. ratificirala zakon broj 2510, o naseljavanju odnosno kolonizaciji. Ovaj se zakon u literaturi smatra najvažnijim zakonom o regulisanju imigracije u Turskoj i bitnim zakonskim sredstvom politike integracije tj. asimilacije Republike Turske nemuslimanskog i neturskog stanovništva. ${ }^{11}$ Ovim zakonom je Turska rekonfigurirala imigracijsku politiku i pokazala spremnost da se suoči sa većim brojem novih imigranata koje je trebalo planski "repatrirati" sa nekih područja Balkana. Tako je već u junu 1935. postignut dogovor između Turske i Rumunije o iseljavanju turskog stanovništva iz Dobrudže, što je godinu dana kasnije, 4. septembra 1936. u Bukureštu, rezultiralo potpisivanjem "Convention réglementant l'émigration de la population turque de Dobroudja". ${ }^{12}$ Tekst te konvencije će kasnije velikim djelom služiti kao matrica za jugoslovensku-tursku konvenciju iz 1938. godine.

\section{Pripremajuće interministerijalne konferencije (1935) i § 55 Zakona o državljanstvu}

Poslanstvo Kraljevine Jugoslavije u Turskoj je vrlo pažljivo pratilo unutrašnji razvoj Turske, a Ministarstvo inostranih poslova nije dugo oklijevalo kad je utvrđeno da je moguće postići sporazum oko iseljavanja neslavenskog muslimanskog stanovništva iz "Južne Srbije". Sve je dodatno potaknuto kada je Aras Subotiću dao do znanja da "misli da bismo početkom naredne godine (1936 - E. P.) mogli zaključiti i formalni sporazum, na sličnim bazama kao što je zaklju-

10 Vidjeti: Ivo Andrić, Diplomatski spisi, priredio Miladin Milošević, Beograd, 1992, str. $134-135$.

11 Kemal Kirişci, "Disaggregating Turkish Citizenship and Immigration Practices", Middle Eastern Studies, 36 (2000), 3, str. 1-22, ovdje str. 4.

12 Andrea Schmidt-Rösler, "Die Auswanderung der Türken aus der Dobrudscha in der Zwischenkriegszeit", Münchner Zeitschrift für Balkankunde, 10-11/1996, str. 125-162, ovdje str. 149-151. 
čen rumunsko-turski. Turska bi polako preuzela u toku 2 ili 3 godine 200.000 tih lica sa naše teritorije Južne Srbije". ${ }^{13}$

Prve pripreme sa jugoslovenske strane se primjećuju već sredinom aprila 1935. godine, još za vrijeme Jevtićeve vlade. Političko odeljenje Ministarstva inostranih poslova je tada obavijestilo generalnog konzula u Istanbulu da izvještaje Generalnog konzulata u vezi sa kolonizacijom koju turska vlada sprovodi u unutrašnjosti, a specijalno u Trakiji (misli se na djelovanje turske strane u sklopu zakona (broj 2510) o naseljavanju iz 1934) smatra "za interesantne i korisne" i da treba i ubuduće "najpažljivije pratiti ovo pitanje". Istovremeno je u tom pismu na temu "Preseljavanje neslovena iz Južne Srbije u Tursku", što samo po sebi puno govori, još naznačeno da će se sastati i jedna interministerijalna konferencija u Ministarstvu inostranih poslova. Bilo je predviđeno da se na njoj cijelo to pitanje pretrese i u tu svrhu je Generalni konzulat zamoljen za mišljenje po pitanjima kao što su: kojim putem izvršiti grupne transporte, koje i kakve korake bi trebalo preduzeti kod turskih vlasti i šta bi trebalo iseljenici od svojih stvari da ponesu. ${ }^{14}$ Do konferencije po pitanju „iseljenja stanovništva neslovenskog porekla iz Južne Srbije" došlo je tek 20. septembra 1935 , za vrijeme vlade Milana Stojadinovića. Za kratko vrijeme zabilježena je velika aktivnost po tom pitanju. Naime, već 24 . septembra se sastao jedan uži komitet te interministerijalne konferencije a 1 . oktobra 1935. održana je i druga interministerijalna konferencija po tom pitanju. ${ }^{15}$

Prije razmatranja rezultata tih konferencija treba pogledati na motive tadašnjih aktera i na društveno-političku situaciju u Kraljevini. Dok je Političko odeljenje Ministarstva inostranih poslova u svom obavještenju Generalnom konzulatu u Istanbulu, sredinom aprila 1935. godine, navelo da „postoji izvesna tendencija kod jednoga dela neslovenskog stanovništva Južne Srbije" - misli se na albansko i tursko stanovništvo - da koristi odredbe člana 55 zakona o državljanstvu, ${ }^{16}$ kojim je regulisan otpust neslavenskih stanovnika "Južne Srbije" iz državljanstva, zapisnik interministerijalne konferencije od 20. septembra navodi nacionalne i vojno-strateške razloge. Naime, Ilija Milikić, šef IV odsjeka Političkog odeljenja Ministarstva inostranih poslova, koji je svojim izlaganjem otvorio konferenciju, argumentirao je da „kompaktne mase Turaka i Arnauta duž arbanske granice pretsta-

13 M. Milošević, n. d., str. 135.

14 Arhiv Jugoslavije (dalje AJ), Poslanstvo Kraljevine Jugoslavije u Turskoj (dalje 370), 370-9-42, listovi 590-591, Pov. br. 9445/35, Beograd, 15. 4. 1935.

15 Rezultate konzultacija od 20. i 24. septembra su objavili Bajrami, n. d. (Rreth përgatitjes), str. 218-220 i Vladan Jovanović, "Interministerijalna konferencija Kraljevine Jugoslavije o iseljenju 'neslovenskog elementa' u Tursku (1935)", Prilozi, 35/2006, str. 105-124. Po sadržaju vrlo sličan Zapisnik i zaključci interministerijalne konferencije od 1 . oktobra 1935. god. nalaze se u AJ, 370-942, listovi 645-650.

16 AJ, 370-9-42, 590, Pov. br. 9445/35, Beograd, 15. 4. 1935. 
vljaju u nacionalnom i vojnom pogledu važan problem".17 Uzimajući u obzir da muslimani koji su sebe smatrali Turcima geopolitički nisu predstavljali bitan faktor, jer je Turska kao „patronatska zemlja" bila previše daleka, a i Kraljevina je u to vrijeme imala dobre bilateralne odnose sa Turskom - može se brzo naslutiti da je fokus u stvari ležao na Albancima, jer je duž albanske granice živilo pretežno muslimansko-albansko stanovništvo. Bojazan od demografskog rasta albanskog stanovništva se ogleda u Milikićevoj konstataciji da se albansko stanovništvo povećalo za oko 65.000 od 1931. godine i da "nacionalizacija neslovenskog elementa [Južne Srbije putem kolonizacije - E. .P] nije uspela". Tako preostaje "jedino još put iseljenja neslovenskog elementa iz zemlje". "Naročitu pažnju" trebalo je obratiti na Albance. ${ }^{18}$

Riješiti manjinsko pitanje putem preseljenja "nepoželjnih" nije bio novitet $u$ istoriji jugoistočne Evrope. Najpoznatiji primjer ovakvog rješenja je Konvencija o razmjeni grčkog i turskog stanovništva iz 1923. godine. No, u slučaju Albanaca Jugoslavije značilo je to dodatno opterećenje inače već krhkih odnosa albanskog stanovništva i državnih institucija. Država je shvaćena kao država južnih Slavena u kojoj su manjinski narodi - Albanci, kao i Mađari i Nijemci - često posmatrani kao nužno zlo. Odnos prema njima pokazivao je ambivalentne crte što se vidi i na primjeru diskusije koja je vođena krajem maja 1928. u zakonodavnom odboru za Zakon od državljanstvu iz 1928. god. i oko § 55 koji je neslavenskim muslimanima "Južne Srbije" široko otvarao vrata za iseljavanje. ${ }^{19}$ Naime, dok je predsjednik tog odbora, ministar unutrašnjih poslova Anton Korošec zagovarao pravo na opciju iseljavanja, njemu su se suprotstavljali članovi opozicije: Svetozar Pribićević, Vladko Maček, Stjepan Radić i Sekula Drljević. Tako je Stjepan Radić polemizirao da „niti najveći neprijatelj naše države ne bi mogao učiniti ono što ste vi stavili u ovaj čl. 55: vlast pridržava sebi pravo, i kaže nekome: traži da ne budeš naš državljanin i beži!"20 No, Korošec je smatrao da se time daje "privilegij Neslovenima. [...] Sve što ovaj paragraf čini, to je u korist Neslovena." 21

Sporni član jeste bio „privilegij” za neslavensko stanovništvo "Južne Srbije", jer nijedna druga grupa to pravo nije posjedavala, i time je $\S 55$ bio u suprotnosti sa načelom jednakosti propisanim

$17 \mathrm{AJ}, 370-9-42,638$, Zapisnik interministerijalne konferencije, 20. sept. 1935.

18 Isto.

19 Po drugom dijelu $\S 55$ dotične osobe su u roku od pet godina (od stupanja na snagu ovog zakona, što je bilo u novembru 1928) mogle da daju izjavu upravnim vlastima da istupaju iz državljanstva. Od dana izjave je trebalo da se odsele iz Kraljevine. Za te iseljenike je trebalo da budu predviđene i olakšice, za iseljenje kao i za prodaju imovine. Vidjeti: Zakon o državljanstvu Kraljevine SHS, Službene novine Kraljevine SHS, X, 254, Beograd, 1928, str. 1294.

20 Stenografske beleške zakonodavnog odbora Narodne skupštine Kraljevine Srba, Hrvata i Slovenaca, Redovan saziv za 1927/28. god., I knjiga, Beograd, 1928, str. 294.

21 Isto, str. 299. Za prijedlog da ostane sporni deo člana 55 glasalo je 15 članova komisije a protiv 13 . Vidjeti: isto, str. 300 . 
u ustavu Kraljevine. S druge strane, produbljena je obostrana percepcija da neslovensko muslimansko stanovništvo nije integralni dio građanskog društva Kraljevine. No Milivoje Milčić (savjetnik Ministarstva inostranih poslova) na interministerijalnoj konferenciji od 20. septembra označio je da je upotreba § 55, barem što se perioda do 1933. tiče, ostala "mrtvo slovo". ${ }^{22}$ Zato je jedan od rezultata konferencije bilo otklanjanje svakojakih teškoća koje bi mogle da ometaju iseljavanje na osnovu $\S 55 .{ }^{23} \mathrm{U}$ prvom planu je stajalo stvaranje posebne konvencije, kako je tog 20. septembra definisano, te da "treba pokrenuti pitanje iseljenja sa turskom vladom i nastojati da se isto reši na sličan način, kao što je to učinila Rumunija, t.j. putem jedne specijalne konvencije". ${ }^{24}$ To je potvrđeno na interministerijalnoj konferenciji 1. oktobra 1935. godine: „1. Pitanje iseljenja treba što pre regulisati specijalnom konvencijom između naše države i Turske, kao i između naše države i Arbanije, a na način kako je to pitanje regulisano između Turske i Rumunije." 25 Iako se ovdje spominje i Albanija, to je po današnjem saznanju ostalo beznačajno. Nije došlo do nekih značajnih koraka u vezi sa planskim iseljenjem albanskog stanovništva u Albaniju. Sa Turskom se očekivalo brzo i efektivno sklapanje jednog bilateralnog sporazuma. Na tome se u Beogradu ozbiljno radilo, što potvrđuje i aktivnost Milana Stojadinovića.

Neposredno poslije interministerijalne konferencije 1. oktobra, Stojadinović je u svom obraćanju kraljevskom poslaniku u Ankari Branku Lazareviću urgirao da iskoristi „povoljnu priliku, koja nam se pruža" ukazujući na pokušaje nacionalne homogenizacije turske vlade i njenog nastojanja da se rješi demografsko pitanje. A zakon o kolonizaciji iz 1934. je po njegovom mišljenju "stavio u izgled neočekivane mogućnosti u pogledu iseljavanja Turaka iz balkanskih država u Tursku" i otvarao mogućnost da među Turke iseljenike "ubacimo i jedan veći broj Arnauta". ${ }^{26}$ Stojadinović je inače preuzeo i ponovio već spomenutu argumentaciju da nacionalni i vojni interesi nalažu „da se ovo neslovensko stanovništvo u južnim krajevima svede na što manji broj, kako bi se moglo uspešno izvršiti preseljenje našeg življa iz drugih krajeva u Južnu Srbiju. To bi se jedino moglo postići iseljenjem neslovenskog elementa u većim masama i po jednom određenom planu van granica naše zemlje." $27 \mathrm{U}$ tom slučaju cilj je jedino

$22 \mathrm{AJ}$, 370-9-42, 639, Zapisnik interministerijalne konferencije, 20. sept. 1935.

23 Vidjeti: AJ, 370-9-42, 649, Zaključak interministerijalne konferencije o iseljenju neslovenskog elementa iz južnih krajeva, održane 1. oktobra 1935. god. u Ministarstvu inostranih poslova. Potvđene su povlastice koje je definisao uži komitet interministerijalne konferencije 24. 9. 1935, od izdavanja besplatnih iseljeničkih pasoša do oslobađanja od regrutovanja itd. Vidjeti detaljnije u: Jovanović, $n$. d. (Interministerijalna konferencija), str. 117-118.

$24 \mathrm{AJ}, 370-9-42,641$, Zapisnik interministeijalne konferencije, 20. sept. 1935.

25 AJ, 370-9-42, 649, Zapisnik interministerijalne konferencije, 1. okt. 1935.

26 AJ, 370-9-42, 630, Str. pov. br. 1426, Beograd, 18. 10. 1935.

27 Isto. 
mogao da bude sklapanje bilateralne konvencije, što se na drugoj strani poklapalo i sa tada vladajućem mišljenjem da se manjinska pitanja riješavaju geopolitičkim istrumentima, tj. migracijskom odnosno iseljeničkom politikom. To nas dovodi i do preispitivanja navedenih motiva: nacionalni i vojni interesi. Naime, iako neslavensko muslimansko stanovništvo u Beogradu nije smatrano integralnim djelom građanskog društva, mada su vodeći srpski političari gledali pozitivno na iseljavanje muslimana iz njihove sfere interesa u Tursku, nije se za vrijeme Kraljevine radilo permanentno na tome da ih se "riješi". Ali sredinom tridesetih godina stvorena je za ovo muslimansko stanovništvo opasna situacija. Korjenite promjene na unutarnjem i posebno na vanjskopolitičkom planu su zaoštravale situaciju za neslavensko, pogotovo albansko stanovništvo "Južne Srbije". Na ideološkom planu je Stojadinovićeva vlada odustala od koncepta „integralnog jugoslovenstva", čime su se jačale nacionalne koncepcije državotvornih naroda i što je za posljedicu imalo unutarnju koheziju dotičnog "nacionalnog korpusa". ${ }^{28}$ Za srpsku (političku) elitu se time postavljalo pitanje pozicioniranja prema državi koja se nalazila u prelomu i na ideološkoj matrici prema konceptu srpstva odnosno jugoslovenstva. A određivanje sopstvenoga uvijek tangira i konstrukciju "drugoga".

\section{Državni akcionizam}

Ionako nevelik manevarski prostor za manjinske grupe se u toj prelomnoj situaciji još više smanjio. Novonastale međunarodne geopoličke promjene su dodatno stvarale ambijent koji je doveo do radikalnih promjena u odnosu prema albanskom stanovništvu, koje je sve više percipirano isključivo kao bezbijednonsno-politički faktor. Promjenom međunarodnog odnosa snaga u Evropi došlo je do širenja italijanskog uticaja u Albaniji 1935. i 1936. godine, ${ }^{29}$ zaoštravanja bilateralnih odnosa između Jugoslavije i Italije, te stvaranja potencijalne visokorizične geopolitičke sfere duž granice prema Albaniji. U tom kontekstu je jugoslovenski vojni izaslanik u Tirani marta 1936, povodom potpisivanja značajnog paketa bilateralinih sporazuma između Italije i Albanije i gledajući na potpirivanje albanskog iredentizma od strane Italije, predlagao načelniku Glavnog generalštaba da se na širem pograničnom pojasu prema Albaniji izvrši raseljavanje albanskog stanovništva u unutrašnjost zemlje $\mathrm{i}$ da ih se iseljava u

28 Vidjeti i Marko Bulatović, "Struggling with Yugoslavism: Dilemmas of Interwar Serb Political Thought", Ideologies and National Identities. The case of TwentiethCentury Southeastern Europe, (ur. John R. Lampe i Mark Mazower), Budapest/ New York, 2004, str. 254-276.

29 Vidjeti Michael Schmidt-Neke, Entstehung und Ausbau der Königsdiktatur in Albanien (1912-1939). Regierungsbildungen, Herrschaftsweise und Machteliten in einem jungen Balkanstaat, München, 1987, str. 257-259. 
Tursku. ${ }^{30}$ Reakcije Glavnog generalštaba nisu poznate, ali znamo da je kratko poslije tog izvještaja došlo do radikalizacije odnosa, te da je krajem aprila 1936. zamjenik bana Vardarske banovine sreskim načelnicima naredio, pod izgovorom suzbijanja "albanske iredente", da se moraju preduzimati $\mathrm{i}$ "mere da se arnautski živalj bilo propagandom bilo izuzetnim merama prisili na iseljavanje u Tursku" i istakao: "zato odmah razvite najjaču propagandu da se kod arnautskog življa u vašem srezu pokrene želja za iseljavanjem u Tursku". ${ }^{31}$ Zanimljivo je da se paket mjera koji se ovdje predlaže samo djelomično orijentisao prema zaključcima interministerijalne konferencije od 1 . oktobra 1935. jer su se sada državni organi više miješali u život običnog seljaka. Zamjenik bana je na primjer zahtjevao da sva djeca, "ženska naročito", moraju bezuslovno pohađati školu, o čemu treba voditi računa, te sve "neposlušnike najstrožije kažnjavati". A iz nacionalnih razloga je trebalo uticati na upravitelje osnovnih škola da uvode večernja predavanja za svu odrasliju djecu i mladež, kojima se mora dokazivati "da oni nisu Arnauti već potomci starih Srba koje su Turci nožem i puškom poturčili" i trebalo in je "nagovarati [...] da uče da pišu i da čitaju državnim jezikom". Na drugoj strani je trebalo strogo kontrolisati muslimanske vjerske škole, pa je za udaljavanje od odobrenog programa traženo preduzimanje mjera da se rad tih škola zabrani. Učenje iz albanskih udžbenika i svako predavanje na albanskom jeziku je trebalo zabraniti. Također se zahtijevalo od sreskih načelnika - dobro znajući da je duhan bio jedan od najvažnijih poljoprivrednih proizvoda "Južne Srbije" - da stupe u vezu sa monopolističkim organima sa ciljem što većeg obustavljanja sađenja duhana u tim krajevima. Zahtjevano je i da se stupi u kontakt sa veterinarskim referentom, koji treba "vrlo često oglašavati za zaražene krajeve, zbog bolesti stoke, naročito onde gde ovaj živalj (Albanci - E. P.) većim delom živi od stočarstva". ${ }^{32}$ Zamjenik bana je bio izričito jasan u definisanju cilja kad je spomenuo "da je tendencija da se krajevi naseljeni arnautskim življem očiste od Arnauta i nasele nacionalnim elementom". No, represivni potencijal i prava opasnost te naredbe ležala je u činjenici da je sreskim načelnicima svjesno otvoren prostor za postupanje van granica zakona: "vašoj umešnosti i sposobnosti" se ostavlja "da [...] razvijete akciju u vašem srezu s obzirom na prilike koje postoje u vašem srezu i sve ono što bi imalo dejstva na arnautski živalj da se iseli, preuzimajte sistematski najenergičnije". ${ }^{33}$

Državni aparat se najkasnije tada i definitivno udaljio od svih normi vladavine prava, što će kasnije vidno otežati albanskom sta-

30 Živko Avramovski, „Pitanje podele Albanije u razgovorima Stojadinović-Ćano januara 1939 i stav nekih diplomatskih i vojnih ličnosti", Godišnjak pokrajinskog državnog arhiva, 1/1965, str. 131-160, ovdje str. 138-139.

31 AJ, Zbirka Milana Stojadinovića (dalje 37), 37-51-315, 41, Str. pov. II br. 6, Skopje, 24. 4. 1936.

32 Isto.

33 Isto. 
novništvu da prihvati jugoslavensku državu. No, uz to slijedi naravno i pitanje da li su se i u kojoj mjeri sreski načelnici tih instrukcija pridržavali. Jer gledajući zvaničnu imigracijsku statistiku Turske, iznenađuje opadanje broja imigranata iz Jugoslavije poslije 1935: od 3.489 u 1935. na 250 u 1936. godini i 65 u 1937. ${ }^{34}$ Znači sumnjiva je uspješnost svega toga, na što ukazuje i jedan kasniji dokument Ministarstva inostranih poslova u kome piše da je cjela ta akcija morala biti obustavljena već septembra 1936. „zbog proizvedenog vrenja među arbanskim stanovništvom". ${ }^{35}$ Pritisak na njih je svakako postojao, što se vidi na broju naseljenih kolonista u "Južnoj Srbiji". Naime dok ukupni porast u prvoj polovini tridesetih godina nije bio značajan, ${ }^{36}$ broj kolonista se u tom dijelu zemlje poslije 1935 . znatno povećao. Od otprilike 11.000 porodica koje su se doselile između 1919. i 1935. godine, ${ }^{37}$ krajem 1936. ih je bilo 14.490 , dvije godine kasnije već 17.280 , a u prvoj polovini 1940. je statistički broj naseIjeničkih porodica porastao na 22.062. ${ }^{38}$

Izvještaji poslanstava Albanije u Skoplju odnosno u Bitolju ${ }^{39}$ za drugu polovinu tridesetih godina također reflektuju djelovanje državnih organa po pitanju iseljavanja neslavenskog muslimanskog stanovništva u Tursku. Jedan izvještaj s kraja jula 1935. ukazuje na to da su državni činovnici čak i neposredno prije prve interministerijalne konferencije u septembru 1935. pojačali propagandnu aktivnost po tom pitanju. U tom izvještaju Generalnog konzulata Albanije u Skoplju, koji je bio namenjen zastupništvu Albanije u Beogradu, opisuje se djelovanje agrarnog povjerenika iz Skoplja u albanskim selima blizu Gnjilana, gdje su propagirane administrativne olakšice za iseljavanje u Tursku u slučaju prodaje zemljišta državi. To se uglav-

34 Istatistik yıllığı, 12/1940-1941, str. 88.

35 AJ, 370-9-42, 894-897, Iseljavanje muslimanskog stanovništva iz Južne Srbije (opšti referat), Beograd, 6. 4. 1939.

36 Statistički zavod je zabilježio 8.219 "stvarno naseljenih porodica" na teritoriji južnih krajeva do kraja 1929. godine. Ministar poljoprivrede Juraj Demetrović je u martu 1933. god. u skupštini naveo podatak o 10.625 naseljeničkih, dobrovoljačkih i optantskih porodica od početka naseljavanja do 1. januara 1933. Vidjeti: Statistički godišnjak 1929, I, Beograd, 1932, str. 453; Bogdan Lekić, Agrarna reforma i kolonizacija u Jugoslaviji 1918-1941, Beograd, 2002, str. 550 (iz ekspozeja Jurja Demetrovića).

37 Jovanović, n. d. (Jugoslovenska država i Južna Srbija), str. 215.

38 Izračunato po statističkim podacima koje je sakupio Bogdan Lekić. Vidjeti Lekić, n. d., str. 461 (za 1936. god.), str. 463-470 (za 1938. god.), str. 471-472 (za 1940. god.).

39 Može se na ovom mjestu spomenuti da su albanski poslanici intenzivno pratili dešavanja na području gdje je živjelo albansko stanovništvo. Za historiografiju su ti izvještaji od velike vrijednost jer prate razvoj iseljavanja u Tursku, kao i napore albanske vlade da se to iseljavanje zaustavi. Pored društveno-političkih pitanja u tim aktima se dosta puta tematiziraju i socio-ekonomski uslovi života na jugu države. Vidjeti materijale centralnog državnog arhiva Albanije u Tirani (Arkivi Qendror i Shtetit, dalje AQSh) u fondu Ministarstva vanjskih poslova (Ministria e Punëve të Jashtme, dalje 251). 
nom odnosilo na besplatno izdavanje iseljeničkih papira, kao i na djelomično preuzimanje putnih troškova. Ovo pak nije važilo za iseljavanje u Albaniju, za šta im je navodno bilo osporavano izdavanje pasoša. ${ }^{40} \mathrm{Na}$ drugoj strani je Tahir Shtylla, albanski poslanik u Beogradu, krajem jula 1937. ukazivao na to da se nepovoljna situacija za manjinsko (albansko) stanovništvo smirila i da je znatno bolja nego u prethodnim godinama. Istodobno je tvrdio da vlasti više ne primjenjuju pritisak kako bi iseljavale Albance i da administracija, kao ni policija, više nije primjenjivala silu kao ranije. ${ }^{41}$

Zapažanja ovog poslanika poklapaju se sa politikom Beograda i djelovanjem jugoslavenskih vladajućih struktura, čiji je rad na terenu i bio u skladu sa razvojem situacije za pregovarčkim stolom $\mathrm{s}$ Turskom. Naime, nakon izrade formalnih prijedloga Ministarstva inostranih poslova u Beogradu za zaključivanje bilateralnog sporazuma i predaju "Lignes générales de l'accord" Turskom poslaniku u maju $1936,{ }^{42}$ značajnijeg napretka u bilateralnim dogovorima nije bilo. Uviđajući da turska strana odugovlači s rješenjem, Milan Stojadinović je za trenutak odustao od sporazuma naredivši poslaniku u Istanbulu da više ne urgira po pitanju konvencije. ${ }^{43}$ I zaista, pitanje konvencije je povučeno sa dnevnog reda, da bi tek u decembru 1937. bilo reaktivirano. Tada je Ministarstvo inostranih poslova preko turskog poslanika u Beogradu ponovo pokrenulo pitanje "iseljavanja u Tursku naših muslimana - Turaka i Arbanasa - iz Južne Srbije". ${ }^{44}$ Reakcija sa turske strane je, po izvještaju jugoslavenskog poslanika u Ankari Branka Adžemovića, mnogo obećavala, jer mu je ministar Aras rekao da on lično proučava pitanje iseljavanje Turaka iz Jugoslavije u Tursku i da je "problem [...] jedino u stvaranju materijalnih sredstava za to". ${ }^{45}$

\section{Sklapanje konvencije i poslednji poduhvati u vezi sa njezi- nom realizacijom (1938-1940)}

U odnosu na konvenciju, kao i na pitanje odnosa države prema (neslavenskom) muslimanskom, pretežno albanskom stanovništvu, 1938. se pokazala kao sudbonosna godina. Sa jedne strane su obnovljeni pregovori između Jugoslavije i Turske rezultirali parafiranjem konvencije 11. jula, dok se, sa druge strane, tretman manjinskog

40 AQSh, 251, god.: 1935, dosije: 185, listovi 173-177, Teper rezerv. (= Strogo pov.) Nr. II/31, Skoplje, 29. 7. 1935.

41 AQSh, 251, god.: 1937, dosije: 126, listovi 334-336, N. 27/XXV Rez., Beograd, 28. 7. 1937 [dopis ministru vanjskih poslova Albanije Ekremu Libohovu].

42 Vidjeti: AJ, 370-9-42, 694 i 697. Šest tačaka "Lignes générales" je obuhvaćalo važne segmente kasnije konvencije kao što su broj iseljenika, razdoblje iseljavanja itd.

43 Vidjeti: AJ, 370-9-42, 716, Str. pov. br. 2879, Beograd, 16. 10. 1936.

44 Vidjeti: AJ, 370-9-42, 772, Str. pov. br. 73/IV, [Beograd] 14. 1. 1938.

45 AJ, 370-9-42, 771, Pov. br. 24/38, Ankara, 12. 1. 1938. 
stanovništva u toj godini znatno promjenio, tj. pogoršao, što je sveukupno uznemirilo muslimane "Južne Srbije". Može se općenito ukazivati i na postojeću korelaciju djelovanja državnih struktura na terenu sa napretkom bilateralnih razgovora vezanih za nastanak konvencije. Uz to se ne smiju gubiti iz vida kako društveno-političke promjene u zemlji u drugoj polovini tridesetih godina tako ni one na vanjskopolitičkom planu. To je znatno doprinjelo tome da su Albanci, kao i Mađari, tada posmatrani primarno kroz prizmu bezbednosnog i geopolitičkog faktora. Indikator tome je znatno pojačano tematiziranje manjinskog pitanja, kao i zaoštrena retorika, koja nije bila prisutna samo u zatvorenim krugovima - kao u Srpskom kulturnom klubu - nego i u javnom prostoru, na primjer u skupštini. ${ }^{46}$ Jedan takav primjer je skupštinski govor člana opozicije i pripadnika Jugoslovenske nacionalne stranke Sekule Zečevića 2. marta 1938. godine. Diskutirajući o prijedlogu zakona o sređivanju i likvidaciji dobrovoljačkih povlastica, ukazivao je na "etničku situaciju" na južnoj i sjevernoj granici, koja po njegovom mišljenju "ne može biti nepovoljnija, jer su nam baš te najosetljivije granice najslabije naseljene našim domaćim, jugoslovenskim življem". ${ }^{47}$ Zečević je upozoravao prisutne poslanike i na to da prema "našim granicama stoje čvrsti zidovi arbanskog, bugarskog i grčkog etničkog organizma, dok je na svima tim granicama naš živalj veoma proređen i mešovit". Rješenje je vidio u kolonizaciji, kao i u razmjeni „inorasnih elemenata", aludirajući na prijašnje bilateralne dogovore i razmjene "turskog stanovništva", pa je i zagovarao "da najpre sa Turskom Republikom, a po tome i sa Arbanijom pristupimo izmeni nacionalnih elemenata, do što je god moguće šire mere". 48 Govor je naišao, po stenografskim bilješkama, na "burno odobravanje i pljeskanje na levici", ali je isprovocirao i žestoku kritiku. U replici se vučitrnski albanski poslanik Šerif Voca Bećirović žalio zbog glasova u skupštini po kojima treba raseliti Albance ukazujući na lojalnost Albanaca prema jugoslavenskoj državi, što je među skupštinskim poslanicima prouzrokovalo "živo odobravanje i pljeskanje kod većine". 49 $\mathrm{Na}$ sličnu argumetanciju i potvrdu lojalnosti ćemo naići u kasnijem memorandumu 22 člana Jugoslavenske radikalne zajednice (JRZ), (djelomično bivših) poslanika i senatora, adresiranom Milanu Stojadinoviću, u kojem su izrazili ogorčenost zbog ponašanja vladajućih struktura prema muslimanima u južnim krajevima. Taj dokument,

46 Edvin Pezo, "Migrations- und Ethnopolitik in Ausnahmezeiten. Jugoslawiens Türkei-Auswanderung unter der Regierung von Milan Stojadinović (1935-1939)", Gesellschaften in Bewegung. Emigration aus und Immigration nach Südosteuropa in Vergangenheit und Gegenwart, naučni skup, (ur. Ulf Brunnbauer, Karolina Novinšćak, Christian Voß), München, 2011, str. 39-59, vidjeti str. 56-58.

47 Stenografske beleške Narodne skupštine Kraljevine Jugoslavije (dalje SBNS), III red. saz. za 1937/38 god., knj. III, od XX do XXXV red. sast. (25. 2. - 15. 3. 1938), str. 234.

48 Isto, str. 236

49 Isto, str. 987. 
datiran 3. jula 1938. ukazuje na pooštrenu situaciju koja je nastala nakon napredovanja razgovora oko sklapanja jugoslavensko-turske konvencije. ${ }^{50}$ Naime, poslije reaktiviranja pitanja vezanih za konvenciju došlo je do značajnog napretka: konvencija je tematizirana u okviru sastanka Savjeta Balkanskog sporazuma u Ankari (25-27. februara 1938), a između marta i maja održane su tri pripremne interministerijalne konferencije u Ministarstvu inostranih poslova, zaključno sa finalnim pregovorima od 9. juna do 11. jula 1938. u Istanbulu, gdje se sastala Komisija za iseljavanje. ${ }^{51}$ Tok pregovora i sadržaj dogovorene konvencije su u međuvremenu dobro poznati. Pregovori su se odnosili na 40.000 porodica (čl. 3) iz 45 distrikta "Južne Srbije" (čl. 2), odnosno današnje Makedonije, Preševske doline i Kosova. Regulisana su bila kako financijska pitanja tako i godišnje kvote iseljenika od 1939. do 1944. godine. To je sveukupno odgovaralo domaćoj nacionalnoj politici u Ankari, kao i Beogradu. Za jugoslavensku stranu je to značilo stvaranje prostora koji je dozvoljavao iseljavanje što većeg broja albanskog stanovništva, za Beograd i "suštinski smisao" konvencije. ${ }^{52} \mathrm{Uz}$ to je i broj iseljenika značajno prekoračio spomenutu cifru od 200.000 osoba, jer je Milan Ristić, kao vodeći pregovarač u razgovoru sa turskom stranom, isposlovao da se djeca mlađa od 10 godina ne uračunavaju u kvotu iseljenika. ${ }^{53}$ Također je u domet mogućeg došlo i prisilno iseljavanje albanskog stanovništva. Naime, Ristić je tu mogućnost u svom izvještaju opisao rječima: „izbegli smo da ma gde spomenemo da će se iseljavati samo oni koji to žele. $\mathrm{Na}$ taj način nama su ostavljene prilično odrešene ruke i za eventualno prisilno iseljavanje." 54

U međuvremenu se situacija na terenu, korelirajući sa stepenom pregovora, pooštrila. Dokaz tome su mnogobrojni leci i peticije koje su cirkulirale 1938. godine, kao i izvještaji albanskih predstavnika u Jugoslaviji, koji sveukupno ukazuju na pojačanu prisutnost fizičkog nasilja. ${ }^{55}$ Već spomenuti memorandum od 3. jula 1938, koji

50 AQSh, 251, god.: 1938, dosije: 107/2, listovi 853-856 (kopije tog teksta se nalaze i na drugim mjestima ovog fonda). Potpisnici su Ugrin Joksimović (Gostivar), Branko Todorović (Galičnik), Milan Dimić (Debar), Časlav Nikitović (Carevo Selo), Špira Hadži Ristić (Skoplje), Kalamatijević (Štip), Stole Dimitrijević (Tetovo), Živko Janačićević (Gnjilane), Milan Glavanić (Priština), Hadži Ljuba Patrnogić (Prizren), Kadri Salih (Gostivar), Zenel Ibrahim (Kačanik), Sherif Voca (Vučitrn), Mustafa Durgut (Orahovac), Bećir Bedri (Suva Reka), Cejović (Ulcinj), Muhamed Zlatko (Debar), Dušan Perović (Negotin), Todorović (Veles), Beširović (Strumica), Popović (Ohrid), Aćim Popović (Preševo).

$51 \mathrm{AJ}, 370-9-42,893$, Iseljavanje muslimanskog stanovništva (opšti referat), Beograd, 6. 4. 1939.

52 Jovanović, $n$. d. (Iseljavanje muslimana iz Vardarske banovine), str. 92.

$53 \mathrm{AJ}$, 370-9-42, 786, Istanbul, 16. 6. 1938.

54 Isto.

55 Vidjeti: Edvin Pezo, Zwangsmigration in Friedenszeiten? Jugoslawische Migrationspolitik und die Auswanderung von Muslimen in die Türkei (1918 bis 1966), München, 2013, str. 282-284. 
ukazuje na opoziciju unutar JRZ protiv iseljeničke politike vlade i na forme solidarnosti između nemuslimanskog i muslimanskog stanovništva, to opisuje ovako:

"ovi mirni i pošteni gradjani uznemireni su glasinama, koje se u poslednje vreme lansiraju, o tobožnjem njihovom iseljavanju iz njihove Otadžbine u tudju zemlju. Ove glasine, iako nisu dobile zvaničnu potvrdu, uporno se podržavaju i dobijaju svakim danom sve ozbilniji karakter tim pre što nalaze potvrde u našoj a još više u Turskoj dnevnoj štampi.

Nažalost, ove glasine dobijaju svoju verovatnost i u postupcima mnogih Državnih organa, koji izlažu zlostavama i šikanima mirnim [sic] muslimanski žival. Pod vidom traženja sakrivenog oružja organi Vlasti nemilosrdno tuku muslimane i ovakvim svojim postupcima prisiljavaju ih, da kupuju oružje i isto predaju kako bi se time otkupili od dalih zlostava. Ovi i postupci agrarnih Vlasti, koje muslimanskom zemljoradniku oduzimaju i zadnji pedanj [sic] zemlje, ostavljajući ga time bez ikakvih sredstava za život, idu u prilog glasinama za iseljavanje muslimana u Tursku.

Ovo sve za muslimana znači veliko razočaranje i izaziva teško osećanje poništenja i zapostavljenosti. [...]

Sve je ovo stvorilo jednu tešku potištenost, neizvesnost i ravnodušnost prema svemu onome što treba da daje potstreka gradjanima za ekonomsku, kulturnu i političku delatnost. Ova[k]va psihoza naročito pogadja političku delatnost. Radi ovoga naša partiska akcija prirodno gubi medju muslimanski življem." 56

Upozoravajući na situaciju na terenu potpisnici su zahtjevali od Stojadinovića da zvanično demantuje "glasine o nekom tobožnjem iseljavanju muslimana" u Tursku, da se "prestane sa oduzimanjem zemlje od muslimana zemljoradnika i da im se oduzeta zemlja vrati. Ovo tim pre što su oduzimanjem pogodjeni sitni zemljoradnici, kojima je obradjivanje zemlje jedini izvor prihoda za izdržavanje" i da se "prestane sa zlostavljanjem i tučem muslimana, koja se vrše od strane organa žandermarije, a pod vidom traženja tobože sakrivenog oružja". ${ }^{57}$

Stojadinović je u svom obraćanju na konferenciji JRZ za Vardarsku banovinu u Skoplju reagovao na pomenute zahtjeve, te priznao da se vode pregovori sa Turskom i ukazao na to da bi se iseljavali samo Turci koji sami izraze želju da se sele. ${ }^{58}$ Pritisak na Stojadinovića i otpor prema konvenciji, kao i prema postojećoj provedbi agrarne reforme je svakako rastao, ${ }^{59}$ pogotovo među albanskim prvacima. U

56 AQSh, 251, god.: 1938, dosije: 107/2, listovi 853-856.

57 Isto.

58 Politika, 5. juli 1938, str. 4.

59 Vidjeti i djelovanje Mehmeda Spahe unutar vlade, koji je kod Stojadinovića i 
ovom se pogledu posebno isticao Ferhat-beg Draga, bivši poslanik i predsednik Džemijeta. Draga je usko sarađivao sa albanskim predstaništvima u zemlji, te odlazio za Tursku gdje je u visokim političkim krugovima agitovao protiv konvencije. ${ }^{60} \mathrm{U}$ Jugoslaviji je uticao na ministra saobraćaja Mehmeda Spahu, ${ }^{61}$ imao je razgovor sa namjesnikom knezom Pavlom i stupio je u kontakt sa Stojadinovićem. Knez Pavle mu je navodno čak i rekao da se dogovorio sa Stojadinovićem da konvencija neće obuhvaćati Albance. ${ }^{62}$

O Draginom uticaju u vladajućim krugovima se ništa detaljnije još ne zna. No, možemo konstatirati da je sa parafiranjem konvencije 11. jula 1938. došlo do zastoja. Po tom pitanju se u drugoj polovini 1938, odnosno do kraja Stojadinovićeve vlade više ništa značajnije nije dešavalo. Razlog tome je najvjerovatnije unutrašnjopolitička situacija u Jugoslaviji zbog koje je Stojadinović raspisao prevremene izbore za decembar 1938, a i u njegovom je interesu bilo da se potencijalni muslimanski birači u "Južnoj Srbiji" ne uznemiruju dodatno. Do daljih razgovora oko realizacije konvencije došlo je tek poslije Stojadinovićeve demisije i imenovanja Aleksandra Cincar-Markovića za ministra inostranih poslova. Tada se situacija na jugu zemlje po svjedočenju Ferhata Drage smirila. ${ }^{63}$

kod ministra poljoprivrede Svetozara Stankovića u vezi sa stanjem na jugu zemlje oštro protestirao. Stankoviću je prebacio da agrarne vlasti u „Južnoj Srbiji" ne rade po zakonu "i time se ruši autoritet države i priprema pogodan teren za rad subverzivnih elemenata". Dodao je i "da je sav rad agrarnih vlasti u suštini očevidno gaženje postojećih zakona i čitavog pravnog poretka, na kome Jugoslavija kao pravna država postoji". AJ, 37-44-295, 514-515, Beograd, 27. 8. 1938. Stojadinovića je upozorio da "ova nasilja, što se vrše nad muslimanima u Južnoj Srbiji, imaju vrlo nepovoljna odjeka i kod nas u Bosni". I zahtjevao je od njega "da se ovim nasiljima učini jednom za vazda kraj i da se u Južnoj Srbiji povrati pravni poredak, kako dolikuje Jugoslaviji kao pravnoj državi". AJ, 37-44295, 512-513, Beograd, 27. 7. 1938.

60 AJ, 370-9-42, 812, Pov. br. 15970, Beograd, 5. 8. 1938. Desetog jula 1938, poslije povratka Ferhata Drage iz Turske, Tahir Shtylla je obavjestio Ministarstvo inostranih poslova Albanije o tome da je Draga, preko svog poznanika Hasana Rize (Soyak) (rodom iz Skoplja), povjerenika Mustafe Kemala Ataturka, stupio u kontakt sa njim, dobivši obećanje da se niko neće protiv svoje volje nenamjerno iseljavati. Vidjeti objavljenu skraćenu verziju tog akta kod Marenglen Verli, Nga Kosova për Kosovën. Profile biografike personalitetesh dhe luftëtarësh të shquar (Studime, skica, publicistikë, dokumente, ilustrime), 1, Tiranë, 2006, str. 220.

61 Draga je predao Spahi memoradnum o zahtjevima Albanaca, među ostalim u vezi sa agrarnom reformom i konvencijom o iseljavanju. AJ, 37-22-175, 374, [Beograd, 8. 9. 1938].

62 AQSh, 251, god.: 1938, dosije: 107/1, listovi 423-425, Nr. 129, Rez., Beograd, 2. 10. 1938 [Pismo poslanika Shtylla kralju Ahmetu Zogu o Draginom razgovoru sa knezom Pavlom]. Može se dodati da je Shtylla u vezi sa tim razgovorom također zabilježio i to da su knez Pavle i Stojadinović Dragi obećali mjesto u senatu.

63 Po izvještaju skopskog lista Naš dom Draga je u okviru zasjedanja vakufskogmearifskog sabora u Skoplju, (8. aprila 1939. god.) nagovjestio da su vlada Stojadinovića i vlada Cvetkovića spriječile oduzimanje zemlje i nasilno iseljavanje i zaštitile građanska prava muslimana. Zanimljiva je i Dragina opaska da je Stojadinović pred izbore tražio njegovu saradnju. Vidjeti: Naš dom, Nezavisni list 
Ipak su uloženi novi napori da se realizuje konvencija. Razlog tome je bilo insistiranje Ministarstva poljoprivrede i Glavnog đeneralštaba da se konvencija ratifikuje i primjenjuje, zaoštravanje odnosa na međunarodnom planu, a naročito italijanska okupacija Albanije u aprilu 1939. godine. ${ }^{64}$ To je početkom aprila dobilo na dodatnom zamahu kada se turski poslanik u Beogradu izjasnio da je Turska voljna odmah potpisati konvenciju, bilo u Beogradu bilo u Ankari. ${ }^{65}$ Razmišljalo se o stvaranju potrebnih organa za izvršenje konvencije ${ }^{66} \mathrm{i}$ iz Ministarstva inostranih poslova je signalizirano Poslanstvu u Ankari da su završene sve potrebne formalnosti oko potpisivanja konvencije, te da će, ako je turska vlada saglasna, poslati tekst i punomoć za potpisivanje. ${ }^{67} \mathrm{No}$, očekivanja jugoslavenske vlade u vezi sa ratifikacijom i sprovođenjem konvencije se nisu ispunjavala. Turska je kočila dalji tok pregovora taktizirajući, odnosno, kao što je Branko Adžemović dobro procjenio, ucjenjujući jugoslavensku stranu. Dali su jasno do znanja da zbog međunarodne situacije ne bi bili u stanju izvršavati konvenciju, sem ako bi Jugoslavija povećala svoj doprinos za finansiranje iseljavanja. ${ }^{68} \mathrm{Na}$ kraju je Beograd pristao. Aleksandar Cincar-Marković je sredinom augusta javio Kraljevskom poslanstvu u Ankari da je vlada "donela odluku na osnovu sporazuma sa Turskom iseliti ove godine 4000 albanskih porodica" i ako se postojeći sporazum ne može primjenjivati onda treba turskoj strani reći da je vlada spremna preuzeti sve transportne troškove kao i deo troškova, koje bi trebalo da snosi Turska. ${ }^{69}$ Ustupci i napori jugoslavenske vlade su ipak ostali bez rezultata iako su se vladajući beogradski krugovi čak i poslije početka Drugog svjetskog rata nadali da će se Turska pokazati predusretljivijom, na šta ukazuje jedan (vjerovatno poslednji) upit u februaru 1940. godine. ${ }^{70}$ Sve je ostalo bez rezultata, konvencija nije ratificirana i sa dolaskom Drugog svjetskog rata na Balkan njena primjena je postala nerealna. Invazijom Italije na Grčku u oktobru 1940. put iseljavanja preko Soluna nije bio više moguć.

Iako konvencija nikada nije ratifikovana, sva dešavanja u sjenci jugoslavensko-turskih pregovora oko nje nanijela su veliku štetu ionako fragilnim odnosima između manjinskog albanskog stanovništva i države sa slavenskim predznakama. Pregovori koji su vođeni 1938. su ubrzo postali javna tajna, ${ }^{71}$ a popratni događaji su u to

za kulturno i ekonomsko podizanje muslimana, 17. april 1939, str. 1.

64 Vidjeti detaljnije: Pezo, n. d. (Zwangsmigration in Friedenszeiten?), str. 185-186.

65 AJ, 370-9-42, 921-922, dokument: Konvencija sa Turskom o iseljavanju iz Južne Srbije muslimanskog stanovništva, Beograd, 5. 4. 1939.

66 AJ, 370-9-42, 924, dokument: Ideje za stvaranje potrebnih organa za izvršenje konvencije o iseljavanju Turaka iz Južne Srbije u Tursku, Beograd, 4. 4. 1939.

67 AJ, 370-9-42, 890, Pov. br. 7678, Beograd, 22. 4. 1939 [šifrovan telegram].

68 AJ, 370-9-42, 892, Pov. br. 266, Ankara, 4. 5. 1939.

69 AJ, 370-9-42, 931, Pov. br. 16449, Beograd, 13. 8. 1939.

70 AJ, 370-9-42, 936, Beograd, 4. 2. 1940.

71 Turski list Cumhuriyet je 25. januara 1938. javio da se vode pregovori oko 
vrijeme pojačali osjećaj nesigurnosti među Albancima, kao i njihovu distancu prema državnom aparatu. Konvencija je postala dio kolektivnog pamćenja muslimanskog stanovništva, a kada je pedesetih godina došlo do najmasovnijeg iseljavanja muslimana u Tursku, to je olako protumačeno kao realizacija konvencije iz 1938 . godine. ${ }^{72}$

\section{Uloga Turske i turska imigracijska politika}

Ideja planskog i ugovorom definisanog iseljavanja je bila prilično rasprostranjena u Evropi u prvoj polovini 20. stoljeća, kao imanentan dio ideje o nacionalnoj homogenizaciji države koja nije marila za manjinsko stanovništvo. U tom kontekstu, ciljevi migracijske politike - uključujući i politiku naseljavanja unutar zemlje - Kraljevine Jugoslavije i Republike Turske bili su kongruentni. ${ }^{73}$ Obe zemlje su na ovaj način htjele da riješe "manjinske probleme" stvarajući nacionalnu državu turskog odnosno južnoslavenskih naroda. S time je konvencija iz 1938. sigurno, kao što je Zoran Janjetović ustanovio, "odgovarala željama vladajućih krugova u obe zemlje". ${ }^{74}$ No, na drugoj razini se Turska u vezi sa iseljavanjem odnosno useljavanjem muslimana sa Balkana u Tursku pokazala kao iznimno važan faktor. Njena useljenička politika je u visokom stepenu uticala na tokove iseljavanja muslimana iz Jugoslavije jer je ograničavala ili omogućavala administrativnim putem potencijalnim emigrantima prelazak iz jedne države u drugu. Broj iseljenika opada poslije 1925/26. odnosno 1934/1935. godine, što je u direktnoj vezi sa turskom migracijskom politikom, a najbrojnije iseljavanje muslimana sa područja Jugoslavije prije i poslije Drugog svijetskog rata u pedesetim godinama ${ }^{75}$ je

iseljavanja 200.000 osoba iz Jugoslavije u Tursku. Vidjeti: AQSh, 251, god.: 1938, dosije: 107, listovi 7-8, Prot. Nr. B. III 9, Tirana, 29. 1. 1938.

72 Tako se i u jednom ekspozeu priremljenom za sjednicu Odbora za unutrašnju politiku SIV-a (18. aprila 1956) ukazuje na to da se šire vijesti o tome da postoji navodno neki tajni dogovor između vlada Jugoslavije i Turske koji predviđa iseljavanje 200.000 Turaka iz Makedonije. AJ, Savezno izvršno veće (dalje 130) 130-992-1502, sveska 1/56: Stenografske beleške sa sednice Odbora za unutrašnju politiku SIV-a, održane dana 18. aprila 1956, dokument: Tempo iseljavanja pripadnika turske nacionalne manjine iz NR Makedonije, str. 16-17.

73 Vidjeti u vezi sa migracijskom politikom kao sredstvom društveno-političke sfere međuratnih godina: Ulf Brunnbauer, "Emigration Policies and Nation-building in Interwar Yugoslavia", European History Quarterly, 42 (2012), sveska 4, str. 602627.

74 Zoran Janjetović, Deca careva, pastorčad kraljeva, Nacionalne manjine u Jugoslaviji 1918-1941, Beograd, 2005, str. 395.

75 Autor navodi na bazi albanskih, jugoslavenskih i turskih podataka da se broj iseljenika u međuratnom periodu vjerovatno kretao između 60.000 i 70.000 osoba i da je većina od njih u prvim godinama poslije 1923. napustila zemlju dok su se između 1952. i 1959, kada je iseljavanje dostiglo maksimum, uselilo u Tursku - prema turskim statističkim podacima - 138.585 osoba. Vidjeti detaljnije za godine između 1918. i 1966: Pezo, $n$. d. (Zwangsmigration in Friedenszeiten), 
omogućeno kada je Turska spremno otvorila vrata za useljavanje. Tako da veza između međuratnih i pedesetih godina nije bila konvencija iz 1938. god. već turski zakon o naseljavanju, br. 2510 iz 1934, čija je (asimilacionistička) intencija bila, kao što je izjavio ministar unutrašnjih poslova Şükrü Kaya u skupštini Turske Republike, da formira državu gdje se govori jednim jezikom, misli na isti način i djele isti stavovi. ${ }^{76}$ Taj zakon je bio na snazi cijelo 20 . stoljeće i njegova primjena je u velikoj mjeri usmjeravala iseljeničko strujanje pedesetih godina. Zakon je otvarao vrata osobama "turskog porijekla" (etnosa) i "turske kulture", pri čemu je znanje turskog jezika de facto bila primarna odrednica. To se najbolje može vidjeti na primjeru jednog cirkulara Glavnog direktorata za naseljavanje iz 1934, gdje su "tursko porijeklo" ili (!) povezanost sa "turskom kulturom" bili vezani uvjetom govorenja jedino turskog jezika. ${ }^{77} \mathrm{U}$ slučaju muslimana Jugoslavije se ovaj uslov pokazao problematičnim jer su pojedinci govorili dva ili tri jezika. Istovremeno su pojedine etničke grupe, kao na primjer Albanci, označene kao nepoželjne za imigraciju u Tursku. Albanci su imali nacionalnu državu i smatrano je da se teško asimiliraju. Drugima, slavenskim muslimanima (Bošnjaci, Torbeši/Pomaci), za koje se smatralo da će se relativno lako asimilirati u tursko društvo, bilo je omogućeno useljavanje u Tursku pod obrazloženjem da su vezani za "tursku kulturu".78

Primjena ovih kategorija, koje su ušle i u tekst jugoslavensko-turske konvencije iz 1938. godine, ${ }^{79}$ kao i selekcija na terenu u južnim djelovima Jugoslavije, gdje je svijest o etničkoj pripadnost bila u dosta slučajeva fluidna, pokazala se problematičnom. Tridesetih godina se to moglo vidjeti i po reakcijama albanskih poslanika u Jugoslaviji, koji su pokušavali da spriječe iseljavanje muslimana za koje su smatrali da su Albanci, što je po njihovom mišljenju bila skoro cijela muslimanska populacija „Južne Srbije". Uz to se može dodati da je i turska strana povremeno imala dosta liberalan odnos prema muslimanima albanskog porijekla. ${ }^{80}$ Nije se to odnosilo samo

str. 51-86. Pregled postojećih procjena u literaturi daju Zoran Janjetović i Vladan Jovanović: Janjetović, $n$. $d$., str. 69-71; Jovanović, $n$. $d$. (Iseljavanje muslimana iz Vardarske banovine), str. 93-96.

76 Vidjeti: Erol Ülker, „Assimilation, Security and Geographical Nationalization in Interwar Turkey, The Settlement Law of 1934", European Journal of Turkish Studies, 7/2008, http://ejts.revues.org/2123, § 7. Vidjeti opširnije o imigracijskoj politici Turske: Soner Cagaptay, Islam, Secularism, and Nationalism in Modern Turkey, Who is a Turk?, London, New York, 2006, str. 82-101.

77 Vidjeti: Ülker, n. d., § 10-12.

78 Isto, § 13-16. Vidjeti i: Cagaptay, n. d., str. 96-97, 99.

79 Član jedan ukazuje na to da će profitirati "les sujets yougoslaves musulmans d'origine et de langue turque et ceux ayant la culture turque". AJ, 370-9-42, 911-912.

$80 \mathrm{U}$ vezi s time i gledajući na izvještaje albanskih predstavništava tridesetih godina se vidi da se turska imigraciona politika pokazala kao kontradiktorna ali i fleksibilna. Dok je još krajem 1932. poslanik u Ankari od ministra vanjskih 
na međuratni period nego i na prvu polovinu pedesetih godina, na što je, na primjer, u septembru 1954. ukazivalo i Savezno ministarstvo inostranih poslova u Beogradu nakon što se turski konzul u Skoplju obratio Izvršnom vijeću Makedonije i zahtjevao od njih da oni za iseljenje „uzimaju u obzir samo prave Turke". ${ }^{81}$ Naime, u Ministarstvu inostranih poslova su smatrali da su turske vlasti bile voljne da prećutno prime i izvjestan broj Albanaca. ${ }^{82}$

\section{Sporazum iz 1953. godine}

Kao što je već spomenuto, tokom pedesetih godina došlo je do najmasovnijeg iseljavanja muslimana od nastanka Jugoslavije. Razlog tome je bio neformalni sporazum između Jugoslavije i Turske iz 1953, koji se često neosnovano poistovjećuje sa konvencijom iz 1938. godine. Modaliteti nastanka i sadržajni okvir tog sporazuma su bili drugačijeg karaktera, a potrebno je istaći i da je inicijativa početkom pedesetih godina došla sa turske strane dok se Jugoslavija u ovom slučaju pokazala pasivnom. Tako je već 1951. turska ambasada u Beogradu tražila da se nekim jugoslavenskim državljanima koji imaju rođake u Turskoj dozvoli odlazak u ovu zemlju. ${ }^{83}$ Kao što je zabilježeno u jednom izvještaju Državnog sekretarijata za inostrane poslove, Ministarstvo inostranih poslova je u januaru 1951, na zahtjev turske ambasade, izrazilo spremnost da razmotri pitanje iseljenja „pojedinih pripadnika turske nacionalne manjine, državljanina FNRJ, u cilju spajanja sa članovima njihove uže porodice iseljenih iz Jugoslavije u Tursku", što je u godinama nakon 1951. navodno bio povod čestih intervencija turske ambasade. ${ }^{84}$ Tako je npr. 1 . jula 1952. turski ambasador Kemal Köprülü sastajući se sa Leom Mate-

poslova dobio obećanje da se i dalje neće primati "Kosovarci" (AQSh, 251, god.: 1932, dosije: 156, list 28, No. 14, Rez., Ankara, 30. 11. 1932 [Pismo albanskom ministru vanjskih poslova]) u izvještajima iz 1934. i 1935. se ukazuje na to da se vize daju i osobama koje ne znaju turski (AQSh, 251, god.: 1934, dosije: 142, list 104) i da je čak i tursko poslaništvo u Skoplju aktivno podržavalo iseljavanje Albanaca (AQSh, 251, god.: 1935, dosije: 185, listovi 122-129, II/XXIII, Teper rezervate [pismo albanskog generalnog konzula u Skoplju Sermet Xhaxhuli ministru vanjskih poslova Albanije, bez datuma, vjerovatno sredinom jula 1935. god.]). No, krajem 1937. je Xhaxhuli iz Skoplja javio da se poslije intervencije albanskog ministarstva inostranih poslova više ne izdaju vize za imigraciju stanovnicima Kosova odnosno Albancima ali i da albanske familije koje govore i turskom jezikom ipak dobivaju vize za posjete Turskoj (AQSh, 251, 1937-126, 421-424, Nr. 28/VIII. Rez., Skoplje, 18. 11. 1937 [Xhaxhuli ministru vanjskih poslova u Tirani]).

81 Arhiv Saveznog ministarstva inostranih poslova, Politički arhiv (dalje ASMIP, PA), 1954, F 97, Beograd, 18. 9. 1954, Radna zabeleška, str. 2.

82 Isto.

83 ASMIP, PA, 1951, F 86, Zapisnik VII sastanka održanog u Ambasadi FNRJ u Ankari, 26. juna 1951.

84 ASMIP, PA, 1954, F 95, [Beograd] februara 1954, Turska, str. 107. 
som, pomoćnikom ministra inostranih poslova, tematizirao "pitanje vraćanje Turaka, naših [jugoslavenskih - E. P.] državljana, u Tursku" i molio da se po mogućnosti izdaju pasoši svima onima koji imaju potvrdu turskih konzulata da mogu da odu u Tursku. ${ }^{85}$ Do konačnog ozbiljnog tematiziranja tog pitanja došlo je međutim tek u januaru odnosno februaru 1953. za vrijeme posjete turskog ministra vanjskih poslova Fuata Köprülüa Jugoslaviji $(20-25$. 1. 1953) tj. neposredno nakon toga. Slika toga je vidno poboljšanje bilateralnih odnosa između Jugoslavije i Turske, što je rezultiralo i potpisivanjem Ankarskog ugovora (28. 2. 1953) između Jugoslavije, Turske i Grčke, te Titova posjeta Turskoj u aprilu naredne godine. Köprülü se u okviru službene posjete sastao sa cijelom vladom kao i sa Titom. Iseljeničko pitanje nije zvanično razmatrano, ali se može pretpostaviti da je tematizirano - da je između Tita i Köprülüa zaista došlo do „džentlmenskog sporazuma" - iako nam za to do sada nedostaje relevantna istorijska građa. Naime ubrzo nakon ove posjete definisani su značajni okviri u vezi sa iseljavanjem jugoslavenskih državljana turske narodnosti. Platformu za to pokrenuo je turski ambasador i ona je izrađena 17. februara 1953. sa Alešom Beblerom, državnim podsekretarom za inostrane poslove, koji se 1954. raspitivao o sadržaju jugoslavensko-turske konvencije iz 1938. godine. ${ }^{86}$ Nakon pokretanja te platforme u februaru, Pravni savjet Državnog sekretarijata za inostrane poslove je početkom marta 1953. dao svoju saglasnost o sljedećem sadržaju platforme:

"1) Pozitivno rešiti sve lične molbe gde je utvrdjeno da se radi o mužu i ženi, deci i roditeljima, slučajevima gde je u pitanju hranitelj. U koliko se ne radi o licima za koja ne postoji zakonska smetnja za iseljenje. Svaku molbu individualno rešavati. [...]

2) Iselenje usloviti zahtevom iseljenog lica za otpust iz našeg državljanstva i izjavom Turske Ambasade da će takvo lice ako mu uvažimo molbu za iseljenje smatrati turskim državljaninom i neće ga više smatrati jugoslovenskim državljaninom."

Istaknuto je da bi trebalo "ograničiti broj porodica kojima ćemo moći dozvoliti prodaju i iseljavanje i time naglasiti izuzetak". ${ }^{87}$

To je potvrdio odnosno ponovio Državni sekretarijat za unutrašnje poslove 9. maja iste godine u svom uputstvu područnim organima gdje je i navedeno da "ne treba praviti teškoće licima koja imaju nameru da se isele". Ponovljeno je, što je također ustanovljeno početkom marta, da treba omogućiti emigrantima da prodaju svoju nepokretnu imovinu prije nego što dobiju otpust iz državljanstva FNRJ da bi se izbjegla nacionalizacija. Uputstvo se završavalo prepo-

85 AJ, 836 (Kancelarija maršala Jugoslavije), I-3-b/851, Str. pov. 1425: Zabeleška o razgovoru druga Matesa sa g. Koprulu-em, ambasadorom Turske 1. jula 1952.

86 Vidjeti: ASMIP, PA, F 96, Beograd, 3. 3. 1953, Pov. br. 91737, Modaliteti za iseljenje naših državljana turske narodnosti radi spajanja sa porodicama koje su već u Turskoj.

87 Isto. 
rukom da se što liberalnije gleda na iseljenje jugoslovenskih građana turske nacionalnosti s ciljem spajanja porodica. Zanimljiva je i procjena DSUP-a u vezi sa kvantitativnim obimom iseljavanja u Tursku. Naime, po njihovim informacijama koje su stigle iz Makedonije, procjenjivalo se da će se broj lica koji će zatražiti otpust popeti na oko $30.000 .{ }^{88}$ Postojala je dakle samo procjena a ne neka kvota ili neki određeni kontingent iseljenika kao što je to bilo u slučaju sa konvencijom. Da je ta spomenuta cifra višestruko premašena, također je rezultat tumačenja pojma porodice. Jer, dok ga je jugoslavenska strana usko definirala - "u najužem smislu krvnog srodstva" - sa turske strane to nije bio slučaj. Oni su u porodicu ubrajali i dalje rođake, stričeve, ujake, tetke, sinovce itd. $\mathrm{Na}$ kraju je preuzeta turska interpretacija, što je značajno proširilo krug potencijalnih emigranata. ${ }^{89}$ Drugi razlog za visok broj iseljenika je sigurno i taj što se za iseljavanje prijavio veliki broj muslimana koji u užem smislu nisu bili jugoslavenski državljani "turske narodnosti", a jedino je toj grupi bilo dozvoljeno iseljavanje. Kako su međutim vlasti određivale nacionalnu pripadnost? Kao kriterijum su 1953. uzeti jezik i nacionalno opredeljenje svakog pojedinca prilikom popisa stanovništva poslije 1944. godine. Oni podnositelji koji su ispunjavali oba uslova smatrani su pripadnicima turske manjine. ${ }^{90} \mathrm{Ne}$-Turci su ipak i dalje pokušavali da se isele iz Jugoslavije, što potvrđuje i uputstvo DSUP-a iz 1955. god. gdje se podvuklo da je ne-Turcima zabranjeno iseljavanje:

"Pripadnicima naših naroda i ostalim nacionalnim manjinama /Šiptarima, muslimanima makedonske nacionalnosti, muslimanima nacionalno neopredeljenim/ neće se odobravati iseljavanje u Tursku. Molbe ovih lica, ukoliko se obraćaju, razmatraće se posebno od slučaja do slučaja. Za njihovo rešavanje važiće opšti kriterijum koji se redovno primenjuje pri otpustu iz državljanstva i iseljavanja iz FNRJ."91

U teoriji je to sve zvučalo jednostavno, ali se pokazalo dosta problematičnim jer su državni organi u Makedoniji pedesetih godina često imali problema sa određivanjem narodnosti potencijalnih migranata koji

88 ASMIP, PA, F 96, Beograd, 30. 10. 1953, Zabeleška.

89 ASMIP, PA, 1954, F 97, Beograd, 18. 9. 1954, Radna zabeleška.

90 ASMIP, PA, 1953, F 96, [Beograd, bez datuma], Prilog br. 4: Iseljavanje turske nacionalne manjine iz Jugoslavije. DSUP je u svom uputstvu od 28. 6. 1955. ponovio direktivu da se, ako je nacionalnost sporna, kao osnovni elemenat za određivanje nacionalnosti gleda na upotrebu turskoga (i kao porodičnog jezika) i da se provjeri za koju se nacionalnost molilac deklarisao pred nadležnim organima poslije 1944. godine. Tek oba elementa su definisala molioca kao pripadnika turske nacionalnosti. AJ, 130-992-1502, sveska 1/56, dokument: Tempo iseljavanja pripadnika turske nacionalne manjine iz NR Makedonije, str. 11. Integralna verzija ovog uputstva je objavljena u: Radmila Radić, "Iseljavanje stanovništva sa jugoslovenskog prostora sredinom pedesetih godina", Istorijski zapisi, 1-2/1999, str. 143-173, str. 161.

91 Vidjeti za ovaj dio upute DSUP-a od 28. 6. 1955. god.: AJ, CK SKJ (AJ 507), XVIIIK.4/7: [Skopje], 9. 2. 1957: Problemi stvoreni iseljivanjem pripadnika turske nacionalne manjine sa područja NRM, str. 4. 
su predali zahtjev za otpust iz jugoslavenskog državljanstva. Nastala je, kao što se izrazio jedan izvještač, „prava zbrka oko utvrdjivanja nacionalne pripadnosti. U praksi se često nailazi na slučajeve da su se is [iz] te porodice jedni deklarisali kao Turci a drugi kao Šiptari. Ili jedno stoji u ličnim kartama a sasvim drugo u matičnim knjigama."92

Pored ravnodušnosti organa vlasti, bio je to sigurno još jedan razlog što su još u 1954. godini vlasti u Makedoniji, kao što je već naglašeno, u kontekstu jedne relativno liberalne politike Turske u vezi sa etničkom pripadnosti iseljenika, „rešavale na isti način molbe Šiptara kao i Turaka". ${ }^{93}$ Ali odnos prema tom pitanju se promjenio najkasnije u aprilu 1956, na šta nam ukazuje jedan izvještaj iz aprila te godine po kome službenici konzulata Turske u Skoplju „odobravaju iseljenje pripadnicima turske manjine i to samo iz Makedonije, a odbijaju Šiptare iz Makedonije i muslimane koji dolaze iz Kosmeta i Sandžaka". ${ }^{44}$ Ostaje naravno uvijek upitno u kolikoj mjeri su administrativne vlasti na terenu postupale prema uputama sa strane viših organa, ali vidljivo je da od druge polovine 1954. postoje administrativni pokušaji da se iseljavanje za Tursku ograniči isključivo na tursko stanovništvo Makedonije. ${ }^{95} \mathrm{Na}$ Kosovu se od toga odstupilo, ali tek 1957. god. kada je iseljavanje u Tursku odobreno i turskom stanovništvu Kosova. ${ }^{96}$

\title{
Summary
}

Dr Edvin Pezo

\section{Comparative Analysis of 1938 Yugoslav-Turkish Convention and the 1953 "Gentlemen's Agreement". Negotiations on the Migration of Yugoslav Muslims to Turkey}

\begin{abstract}
Key words: Milan Stojadinović, Yugoslav-Turkish Convention (1938), "Gentlemen's Agreement" (1953), interministerial conference (1935), citizenship law (1928, §55), state repression, Turkish immigration policy.
\end{abstract}

92 AJ, 130-992-1502, sveska 1/56, Stenografske beleške sa sednice Odbora za unutrašnju politiku SIV-a, održane dana 18 aprila 1956, dokument: Tempo iseljavanja pripadnika turske nacionalne manjine iz NR Makedonije, str. 11.

93 ASMIP, PA, 1954, F 97, Beograd, 18. 9. 1954, Radna zabeleška.

94 AJ, 130-992-1502, sveska 1/56, Stenografske beleške sa sednice Odbora za unutrašnju politiku SIV-a, održane dana 18 aprila 1956, dokument: Tempo iseljavanja pripadnika turske nacionalne manjine iz NR Makedonije, str. 17-18.

95 Vidjeti detaljnije o pokušajima vladinih restrikcija prema neturskom stanovništvu za period do 1957. god.: Pezo, n. d. (Zwangsmigration in Friedenszeiten?), str. 307-312.

96 Isto, str. 311-312. 
When comparing the genesis and contents of the $1938 \mathrm{Yu}-$ goslav-Turkish Convention with the 1953 "Gentlemen's Agreement" it can be concluded that there was a certain similarity but no continuous policy of Muslim population migration from Yugoslavia to Turkey. The role of the Yugoslav government regarding this issue greatly changed when we compare the thirties and fifties. During the thirties the government in Belgrade mostly due to geopolitical reasons endorsed a planned migration of non Slav Muslims, mostly Albanians. The government headed by Milan Stojadinović, who was the initiating force behind the process, endorsed a joint agreement with Turkey. Furthermore, repressive measure were also undertaken to encourage migration and create a right atmosphere for it. That was not the case in the fifties when Turkey was the initiator for a joint agreement that was to enable the migration of "Turks" to Turkey. The initiative and request this time came from Turkey. The Yugoslav side took a passive attitude at that time and obliged Turkey on the issue by limiting migration of the non Turkish population. All in all, the fifties agreement had a completely different character then the one from the thirties where etnopolitical dimensions dominated. Differences can be seen on the issue of repression, that is, focused use of violence by the state. Repressive measure overlapped with the negotiations of the governing structures on the convention while similar repressive measures against the emigrating Muslim population did not exist in the fifties. The only incidents that could possible fit into this context are the events that took place at Kosovo in the winter of 1955/56. At that time a campaign was conducted to collect weapons from the population, however a scholarly study on the course and dynamics of these events is still lacking. What is known is that violence was used to a great extent on that occasion and it resulted in the probable death of a several tens of people. These events surely influenced parts of the Kosovo population to migrate to Turkey via Macedonia. But in the author's opinion these events cannot be directly connected with a certain planned action for a forced migration of Albanians. If the state had such intentions it would have created the necessary administrative conditions as was the case in the thirties. The authorities would at least have allowed or made easier the migration of the Albanian population from Kosovo, which was not the case. 